\title{
Turkish Foreign Policy in the Middle East After Arab Spring
}

\author{
Mahmoud Khalifa \\ Suez Canal University, Ismaïlia, Egypt
}

\begin{abstract}
Turkish policymakers' main focus was on how to play an effective regional role in the events and issues of the Middle East, such as mediation in resolving conflicts. Consequently, the paper will attempt to address the following questions: What is the impact of Turkish foreign policy towards the Arab Spring under Justice and Development Party (AKP: Adalet ve Kalkınma Partisi) rule? What is the future of Turkey in the Middle East in light of the revolutionary variables in the region? The main aim of this paper is to explore Turkish foreign policy towards the Middle East under the AKP rule particularly after the Arab Spring. The paper attempts to anticipate the future of Turkish foreign policy and Turkey's role in the Middle East.
\end{abstract}

Keywords: Turkish foreign policy, Arab Spring, Middle East

\section{Methodology}

Largely, the research methodology is depended on reading and analysis the Turkish foreign policy process in the future in the Middle East through an analysis of a group of alternatives, which are known as "forecasting" or "scenario analysis".

The scenario analysis is the main method of expectations, this research does not pose one image of expectations or scenarios but it provides several dynamic alternatives in the future for the Turkish foreign policy. Thus, the range of possible outcomes for each scenario can be observed through a descriptive analysis of the Turkish foreign policy, which is built on the common interest principle.

Sometimes, the analysis of each scenario can be used for "extrapolation of past" which means it can rely on historical data or information and conclude it for forecasting the future. In addition to, the research tries to review all the potential improvements of Turkish policy in the international relations.

Finally, in the research, the scenario analysis generally has approved a number of scenarios through "scenario analysis" which shows the potential consequences in the future and concluded the most likely scenario.

\section{Introduction}

The Turkish role in the Arab region has passed through three distinguished stages.

Firstly, the period since the declaration of the Turkish Republic (1923-1989) after World War I witnesses adherence to principles and policies that favored the west and ignored the Arab region. The period between 1923 and 1929 is called the "liberal era" while the period between 1929 and 1938 is called the "étatism era". (Takim \& Yimaz, 2010, p. 549). In 1987, "Turkey submitted its application for official membership to the European Community. In December 1989, the European Commission responded by confirming Ankara's 
eventual membership" (CIDOB, 2011, p. 228).

In this period, the Turkish attitude towards the Palestinian cause was balanced though it supported Israel and the policy of the west and the Atlantic.

Secondly, the period of 1990s witnessed the emergence of the "New Ottoman" when president Turgut Ozal came to power and expressed the Turkish desire to play a more influential role in the Arab region through participating in territorial western-Israeli project to reformulate the region and make use of its oil and markets. In the first years of the Ozal government, Turkey was under European and American heavy pressure on human rights and democratisation issues (Laciner, 2009, p. 172).

Thirdly, since the rise of Justice and Development Party (AKP) to power in November 2002, the evolution of Islamic modern political force was facilitated by external pressures for reform. If Western governments hope to see this evolution take place across the Middle East, they would do well to study closely what is happening in Ankara (Patrick, 2004). And the use of new strategy towards the Arab region based on openness and problem-solving in relation to zero-problem theory, strategic-depth theory, multi-dimensionality theory and initiative policy. And the paper will discuss the third phase particularly after Arab Spring.

In the beginning of late 2010, the Arab region witnessed a number of unprecedented, radical political events and transformations. These events were surprising in their nature, speed, and the way they spread from one country to another. Surprisingly, these changes caused confusion to many of the parties in the Arab region attempting to find out how to deal with them, at least in their early stages. These protests are widely known as the Arab Spring.

Due to its close geographical position and increasingly prominent role in the Arab region, Turkey was the most influential, as well as the most influenced, by the events that AKP won the elections of 2002. The effects of the Arab Spring posed a major challenge to Turkey's foreign policy, particularly regarding its relations with regimes and publics, while trying to maintain its credibility. Turkey had to determine its stance on the changes in the Arab world. The potential for confusion could lead to the loss of credibility as it has previously based its foreign policy on its good neighbor policy and the principles of freedom, justice, and non-interference in domestic affairs.

Turkey was in favor of peaceful transitions that would not affect its past efforts in the region. The Turkish approach towards the revolutions was especially confused in the early moments of the revolutions. This attitude changed from time to time according to the nature and size of the Turkish interests in each country. Whereas Turkey supported the revolutions in Tunisia and Egypt (Sumer, 2013, p. 19), it showed a reserved or conservative attitude towards the revolutions in Libya and Syria and almost ignored the situation in Yemen and Bahrain. This confusion was addressed in criticism from Arab officials and publics regarding the motives behind Turkish policy towards events, policy that has been described by some as "Machiavellian" as Machiavelli promotes a democratic rather than an aristocratic republic (Ardito, 2015, p. 134).

\section{The Turkish Position Towards the Tunisian Revolution}

In the very first moments of the Tunisian revolution, Turkey did not interfere and kept a low profile as many countries that were surprised by the rapid escalation of events (Ozkan \& Korkut, 2013, p. 170). There was no clear position towards events that were regarded as protests and there was an expectation that the anger of the masses may subside at any moment or overcome by security authorities in Tunisia. This uprising was not expected to be the beginning of the Arab Revolutions. 
When Tunisian president Zein El Abideen Bin Ali fled at night to Saudi Arabia under the pressure of the revolution, Turkey declared its support to the Tunisian Revolution and was stood by the people of Tunisia who claimed their rights to freedom, development, participation and a decent quality of life. At that time, the Turkish foreign minister Ahmet Davutoglu said that the "Tunisian revolt could be model for other countries seeking reform" (Reuters, 2011). Turkey started practical procedures to support the new regime in Tunisia politically and economically. It provided economic support and signed a number of agreements, including one that provided Tunisia with a low-interest loan of one billion dollars, repayable over a period of 10 years, to revive the economy in some sectors that collapsed as a result of recent events. Entry visas for citizens of both countries were also abolished.

\section{The Egyptian Revolution of January 2011}

Since the very first moments of the Egyptian Revolution on 25 January 2011, Turkey took advantage of this revolutionary event by setting out to strengthen relationships with the new regime and gain the trust and sympathy of the Egyptian people. It declared its support to the people in what was considered as a hasty step in the interference in the Egyptian international or domestic affairs. At that time the Turkish Prime Minister Recep Erdogan addressed the former Egyptian President Hosni Mubarak and asked him to listen to the demands of his people and step down for god's sake. He reminded him that all people are mortals, not immortal and that each one will die and will be buried in a two-cubic-metre hole in the ground (Hürriyet Daily News, 2011).

This was seen by many observers and analysts as an explicit intervention into Egyptian domestic affairs. At the same time, the Turkish government invested in the revolution in Egypt to restore relationships with the United States and the European Union and propagate itself as the ultimate guarantor of regional stability in the future, making use of public support. It gained in the region during the first two periods of the reign of the AKP 2002-2010 as well as its strong relationship with the Muslim Brotherhood in Egypt and the region and its soft power, For example, in his message of congratulations to Turkish Prime Minister Recep Tayyip Erdoğan, Mahdi Akef, the supreme guide of the Muslim Brotherhood in Egypt, described the elections as "evidence" of the ability of Islamic parties to achieve "constitutional, political and economic development and social reform" when operating in a democratic, free and fair environment. Similarly, a leading member of the Brotherhood, Essam El-Arian pointed out that the success of the AKP reveals that "a political party does not have to be limited to Islamist members alone" (Arslantas, 2013, p. 128).

Therefore, Turkey proposed to provide support to the new regime after the revolution and to strengthen economic and political ties in different fields and to exchange diplomatic visits. The first foreign visitor to Cairo after the success of the revolution was the Turkish President Abdullah Gul who came as the head of an official delegation. He met Field Marshal Tantawi, head of the Supreme Council of the Armed Forces (SCAF), and a number of representatives of youth movements and political parties. The next visit was conducted by the foreign minister Ahmet Davutoglu who came to Cairo immediately after the formation of the first Egyptian government after January Revolution and met Dr. Nabil Elaraby as a foreign minister.

A third visit was conducted by the Turkish Prime Minister Recep Erdogan who came to Cairo with an official delegation, including a large number of Turkish businessmen and investors, to sign a number of economic and trade agreements between the two countries (Abdel-Meguid, 2012).

At that time, Turkey showed a great interest in developing relationships with Egypt and declared its desire to collaborate with Egypt and establish a new democratic coalition in the region positioning them as the two 
most important countries. The Turkish Prime Minister said that there is no power competition between the two countries and declared that his country prefers a strong Egypt to guarantee stability in the region, and that Egypt's strong position would serve Turkish political, economic and security interests as well as for all other countries in the region. He stated that during an interview with American New York Times newspaper in September 2011 after his visit to Cairo (Kirkpatrick, 2011).

The Turkish attempts to emphasize the significance of Egypt after the January 2011 Revolution and to foster relationships with Egypt based on the fact that Egypt is the closest and most important country to Turkey in the region. Most of the Turkish symposia, discussions and attitudes at that time made this connection between the future of the Turkish role in the region and its relationships with Egypt. Therefore, Turkish interest in Egypt in different official and political aspects increased to improve relationships in different political, economic and military fields by signing a number of military, investment and trade exchanges between the two countries. A number of mutual military maneuvers and tactical exercises were carried out by the armed forces of the two countries. However, all aspects of collaboration between the two evaporated after the fall of the Muslim Brotherhood regime in Egypt on 30 June 2013. Turkey declared that what happened in Egypt on the 3 July was a military coup against the first freely elected Egyptian president. Turkey refused to admit the legitimacy of the new regime and led an international campaign against the new regime which led to a decline in their relationship and "Turkish-Egyptian ties cannot be normalized" (Cagaptay \& Sievers, 2015).

This decline, along with failure in the Syrian situation was a painful setback for Turkey's role in the Arab region. This deterioration in the Turkish role started as a result of the Turkish position towards the events in Egypt because Arab states of the Gulf at that time supported the 30 June Revolution in Egypt. Consequently, Turkish interests and investments in the Gulf were negatively affected because these countries used to be an important market for Turkish products. Since then the Turkish role in the region deteriorated and lost its momentum.

\section{The Turkish Position Towards Libyan Revolution}

Turkish foreign policy towards the events of the Libyan Revolution was characterized by confusion due to the great amount of Turkish interests and investments in Libya. Thus, Turkey was confused between interests and principles. Whereas it has to support the Libyan people in their revolution against the regime of Muammar Gaddafi, it would have to sacrifice its billion-dollar investments and Turkish firms in Libya (Doha Institute, 2011). There are about 160 Turkish companies investing in Libya. Turkey and Libya launched visa exemption on April 19, 2009. Exports rose to 1.9 billion from 1.8 billion between 2009 and 2010. However, Turkish exports to Libya had a significant decrease due to Arab Spring and fell to 747.7 million USD in 2011 (The Tripoli Post, 2012).

Turkey earned 526 million USD from its exports to Libya in the first quarter of 2012. There were also close personal relationships between Gaddafi and Erdogan that increased the confusion of the Turkish policy towards Libya. "Only in December 2010, Erdogan received the Qaddafi international prize - a questionable award even before the advent of the rebellion" (Barkey, 2011, p. 10). At the beginning Turkey rejected the scheme of North Atlantic Treaty Organization (NATO) based on the use of force and the establishment of a no-fly zone in Libya (Lindenstrauss, 2012, p. 9). This scheme was regarded by Erdogan as risky, negative and claimed that there were traditional powers like France trying to restore their colonial role in North Africa which would affect Turkish interests negatively, and during Davutoğlu's visit, he said "It was time for leader 
Muammar Gaddafi to leave Libya", declaring the NATO backed rebels' National Council "the legitimate representative of the Libyan people" (Murinson, 2012, p. 21). However, Turkish officials realized that the confusion during the first weeks of the Libyan Revolution would negatively affect the image and reputation of Turkey among the Arab peoples, especially after its position towards revolutions in Tunisia and Egypt. Some researchers explained the Turkish attitude as a kind of political realism used to strike a balance between profit and loss in regard to the amount of Turkish investments in Libya of about billions of dollars in the field of construction.

Politically, there is a strong relationship between Gaddafi and Erdogan and that is why Erdogan tried to find a solution to the crisis and made a proposal to reach a compromise between Gaddafi and the revolutionaries, not to mention the fact that Erdogan was given the Al-Gaddafi international prize for human rights as we mentioned above. All in all, Turkey's unstable reactions towards the Arab revolutions have negatively affected the image of Turkey among Arab citizens especially after the confusion towards the Libyan Revolution and the NATO military intervention in Libya based on the resolution of Security Council (Craeyvelt, 2013, p. 50).

The Turkish approval of the military intervention in Libya was regarded by many Turkish as pragmatic and an attempt to take part in the reconstruction process in Libya which proves pragmatism rather than steadfast principles in the Turkish foreign policy towards the Arab region.

\section{The Turkish Position Towards Yemeni Revolution}

The Turkish position towards the Yemeni Revolution remains unclear. The sole Turkish official response during the Yemeni Revolution was a statement given by the Turkish foreign minister, Ahmet Davutoglu, in which he said that the Yemeni situation is highly critical in his visit 2012 (Tremblay, 2013). Turkey provided humanitarian and institutional aid to help Yemen to build stability and institutions. With regarding to the Arab Spring countries where the previous leaders were toppled, Turkey eventually developed a policy of either building new ties or protecting already established relations with Yemen (Saadan, 2012, p. 10). And Turkey was not late to show its position regarding Yemeni war. It supports the Saudi-led mission against Houthi forces and has been informed in advance by the kingdom about the military operation (Cengiz, 2015).

\section{Future Scenarios of the Turkish Role in the Arab Region}

In the first phase of the reign of the Turkish AKP, the Turkish government adopted a balanced foreign policy towards its territorial neighborhood and the Arab region applying zero-problems policy, multidimensionality, equality and mediation to solve chronic regional problems (Kibaroglu, 2012, p. 86).

Turkey's success in solving some problems gained Turkish current territorial position as it made use of the absence of classic Arab powers (e.g. Egypt) that were involved in domestic issues at the expense of their external role. Politically, Turkey became an effective leading power and economically it achieved a number of gains through signing a number of trade agreements and establishing economic coordination councils with a number of the Arab countries (Habibi \& Walker, 2011).

Yet, Turkey's confused approach towards the events of the Arab revolutions and the focus on the ideological agenda of Turkish foreign policy towards recent regional events supporting the Muslim Brotherhood movement to rise to power in the Arab countries at the expense of other political powers and tendencies caused Turkey to lose its positive image among Arab citizens. Currently, Turkey is continuing to 
lose ties with the Arab world (Salem, 2011, pp. 1-8).

Despite attempts made by Erdogan to discard accusations of using religion in his party and policy since he was a Prime Minister, and to prove that his party is not based on religion, he conducted a number of democratic reforms within the Army, the judiciary and the constitution, and took his position towards the 30 June 2013 events in Egypt and the downfall of the Muslim Brotherhood, emphasizing the ideological tendency of his party and his foreign politics and negatively affected the Turkish role (Cagaptay \& Sievers,, 2015).

Foreseeing future or predicting future scenarios is a difficult process when surrounded by the instability of events in the Arab region. Thus, most ideas proposed on the Turkish role in the future are nothing but hypotheses that should be revised and considered in progress. As indicated in this research, three scenarios of the Turkish role in the region can be distinguished.

There are so many questions nowadays about the future of the Turkish role in the Arab region according to current events and changes related to the Arab Spring. For example, is Turkey trying to employ the Arab Spring to control the region through supporting Islamist movements?

Is Turkey trying to present the experience of the Turkish AKP as an example to be followed after the Arab revolutions? Does Turkey try to restore the glory of the Ottoman Empire in what is described by some as the New Ottomans or New Brotherhood? Is Turkey trying to do so by employing zero problems and strategic depth policies?

Answers to these questions will be given in the conclusion which will also provide more questions that can be discussed as future research projects. Such questions will be answered according to the current Turkish policy in the region as well as Turkish ambitions during the preparation of the study. Is Turkey satisfied only with improving its relations with Kurdistan in Iraq and achieving some economic benefits at the expense of its regional role?

Does Turkey accept the establishment of a Kurdish country in the north of Iraq? Has Turkey changed the principles of its foreign policy that was established before and during the American invasion (occupation) of Iraq in 2003? Does Turkey accept the increasing Iranian role in the region especially in the war against Intermediate System to Intermediate System (ISIS) and does not care about what happens to the Iraqi Sunnis at the hands of Shiite militias?

As for the Palestinian cause, did Turkey accept to maintain relationships with the Zionist state after the incident of the Gaza Freedom flotilla attack and its poor apology? Did Turkey waive the condition of lifting the siege on Gaza and its support of the Palestinian cause which made Turkey gain the love and support of the Arab peoples? Is Turkey busy with its domestic affairs since the incidents of Taksim Square at the expense of its regional role? Is the Turkish role deteriorating since its inappropriate response to the Syrian crisis? Was the last events in Egypt related to the downfall of the Muslim Brotherhood and the outset of Morsi in 30th of June affected the Turkish role especially after the support of the Turkish Prime Minister of the Muslim Brotherhood and rejection of what happened in Egypt as a coup? Is the Palestinian cause still on the Turkish agenda?

As for the future vision of the Turkish role in the Arab region, one can say that speaking of future in political sciences as well as international relations in a time of rapid changes and political liquidity in the last four years will be a kind of prediction. In light of the indicators that have been explained in the research, future scenarios of the Turkish role in the Arab region can be discussed as follows.

\section{The Turkish Model Scenario}


This scenario is based on the use of a purely Turkish foreign policy that has many dimensions and depends on a high degree of self-confidence and independence to develop positive and efficient relationship with the world. There are two strategic visions behind this scenario.

(1) Strategic depth vision proposed by Ahmed Davutoglo which he discussed in his book Strategic Depth: Turkey's International Position in 2001 (Walker, 2007, p. 33). When the AKP came to power in 2002, it adopted this theory and made it the constitution or the principles of the new foreign policy.

(2) Ozal territorial vision is based on that Turkey's relations with Middle East countries were improved, particularly in the economic sphere and integration between countries of the region to satisfy their social, cultural and economic needs and to solve their security problems (Laciner, 2009, p. 177). This vision seeks to extend communication channels and dialogue among governments of the region as well as people of the Middle East and create a mutual territorial mentality. What Washington could/would do is the significant question that determines Turkish regional and international relationships.

Turkish foreign policy makers believe that the improvement of relations between Turkey and the United states is based on the change in American policy towards the region. Therefore, proposals given to the United States call for two important and urgent modifications in American policy towards the Middle East: (1) Pressure on the Kurdish government in Iraq to stop the forces of Kurdistan workers' party (PKK) permanently and reestablish bonds of trust between Turkey and the United states; (2) The American role in solving the Palestinian cause, achieving justice and applying international laws will relieve tension, which would in turn affect the Turkish role in the Middle East as well as the Turkish public opinion. The Turks believe that these changes will positively affect American policies towards Turkey as well as the American policies towards the Middle East and the Islamic world. They urge Washington to extend means of consultation with Ankara regarding American policies towards the Middle East. They regard Turkey as a leading political and military power in the region that should be part of the American plans.

\section{The Decline of the Turkish Role Scenario}

Reading the Turkish positions towards the Arab Revolutions and its bias to a certain political tendency or ideology at the expense of other political parties and tendencies for the Turkish position to be hesitant towards the revolutions which threatens its credibility among the Arab peoples.

Turkey is considered as a country whose foreign policies are based on principles of freedom, justice and humanity. The Turkish recent positions towards Libya and Syria as well as Egypt after the downfall of Muslim brotherhood in 2013, indicate that many of the political elite in the region started to become anxious and believed that Turkey's positions and policies are part of the restoration of the Turkish role. It had been in decline since the downfall of the Ottoman Empire in the past century by playing the role of the regional equilibrium agent in an unstable and wavering stage in the history of the region.

The decline of the Turkish role could be the result of the Turkish interest in domestic affairs, because of the effects of regional events on the Turkish society such as fearing revolutionary transfer, or the increasing tensions in the conflict with the Kurdistan workers' party. There are also accusation of corruption and weakness of the Turkish government by the Turkish opposition. There are examples of instability including strikes, riots, conflicts with opposition parties, attempts to outset the government, accusations of corruption, violations against journalists and opposition leaders, etc.

Still, Turkey is an important and effective country in the events of the Arab region. It has a lot of 
experience about the events of the region as well as its geography, which makes Turkey a significant country with great capabilities that makes it a true player that is indispensable in regional events. Turkey's powerful position has been proven in recent events especially after king Salman Bin Abdulaziz came to power in Saudi Arabia, because of the need for the Turkish role. Therefore, there should be an objective evaluation of the Turkish role without having to depend on it entirely or ignore it entirely. Turkey, due to its geographical position, is an essential player in many of the current issues taking place in neighboring countries such as the Iraqi situation, Iran nuclear negotiations and relationships with Syria. Turkey also takes part in a number of regional issues beyond its borders. However, the complex nature of events and issues in the region as well as complexities inside Turkey are controlled by internal and external factors that determine the efficiency of the Turkish role. The Turkish role is also determined by other regional roles and powers, some of which are initiative, others contradict the Turkish vision, and still others have to fulfill their responsibilities before depending on the Turkish role to strike a balance between the Iranian role and its development in the Arab region after Iranian-supported Houthis controlled most of Yemen.

\section{The Rise of the Turkish Role Scenario}

Once again the Turkish regional role is increasing as an essential player in strategic balance, security and stability after the increase of Iranian regional role in Iraq, Syria and Lebanon and the creation of conflict zones as a result of Iranian-supported powers taking control over these countries by force at the expense of other powers as in Iraq since the American invasion in 2003 or disturbing security and stability of neighboring countries as in Yemen since Houthis came to power by force after ousting the elected authority. As a result, Saudi Arabia feels threatened by Iranian-supported allies in the south and in the north. The rise of the Turkish role started when King Salman came to power which gave Turkey the opportunity to restore its significance after the decline of the Muslim Brotherhood regime in Egypt in July 2013. A number of mutual official visits took place with the visit made by the Turkish president to Saudi to attend the funeral of the late Saudi King Abdulaziz and another visit by Erdogan a month later when he was invited at the same time with the Egyptian president AbdulfattEl-Sisi. It was argued then that Saudi Arabia was trying to achieve reconciliation between the two countries which will become, along with Saudi, an alliance to be led by Turkey to face or oppose Iran's growing influence in the region.

These events coincided with the arrival of a new leadership in Saudi Arabia carrying a new vision of foreign policy in face of the danger that threatened its security and stability and is looking for a new regional alliance to support its vision including the renewal of its alliance with Turkey as a regional power to confront Iran. However, this alliance is faced with a number of obstacles such as the deterioration of the Turkish- Egyptian relations as a result of the Turkish position towards the 30 of July 2013 as well as the complexity of the situation in Syria. Turkey considers that the new changes support its vision and strategy to solve the Syrian crisis through cooperation to topple the regime of Bashar Al-Assad, Iran's ally, and establish a new pro-Turkey regime and this is what turkey sought for since the beginning of the Syrian crisis in 2011. If this happens in Syria along with reconciliation with the new Egyptian regime through Saudi mediation, it is in dire need of the reconciliation between the two countries to maintain stability in the region. Turkey will greatly succeed in developing its regional role in the future because it is the most capable of the three countries of the leadership of this alliance because of its relative political stability which is based on stable institutions and successful economic experience. 


\section{Conclusion}

The three scenarios have related with a political improvement of a contemporary Turkish foreign policy. In the last coup which occurred in July 15, 2016, after excluding the foreign policy minister Davutoglo, and in addition to the growing problems in the light of Zero Problem Policy, the first scenario "the Turkish model scenario" evaporates the possibility of achieving it. But the prediction of the decline of the Turkish role scenario is temporary, and will not continue because of the failure of the coup, and the return of the ruling regime.

It can be concluded that the Turkish foreign policy toward the Middle East became variable according to each position based on multiple policies towards each country separately. It is similar to the American foreign policy which is based on the idea of the national interests. For example, the latest developments in Syria whether internal or regional, pay an active Turkish policy towards the future political settlement in Syria, and the evidence of the military presence in the northern border of Syria restricts the Kurdish role there.

Turkish foreign policy is in line with Saudi Arabia's foreign policy and with the Saudi role in Yemen, the Turkish foreign policy has became more inclined to Saudi attitudes toward the latest developments in Yemen, and then Turkey's foreign policy towards Yemen was not in the favor of it.

For Libya, there is a totally different vision. The complexity of the situation in Libya and the presence of more than one party in the political and military game mean that there are more than three competing governments in Libya, as well as the complexity of the international and regional situation in Libya. All of these pose challenges to the survival or continuation of Turkish foreign policy towards Libya, but it is concluded that Turkey became outside the game of balance of interests and not one of the political actors in Libya.

From here, the probability of the fourth scenario for the Turkish foreign policy exists (with reservations on the term scenario) and is combined between the previous three scenarios. It is a new trend in Turkish foreign policy but it does not based on scenario in itself, which based on national interest as we mentioned above, and the evidences of that the Turkish foreign policy towards Iraqi Kurds is good while with Syrian Kurds is bad, and its relation with Saudi Arabia and Israel is good and this is a contradiction in itself. Also there is a good relationship with the United States while its relationship with Russia began to improve recently. We also find a distinctive relationship with the Syrian opposition groups and seek to improve its relationship with the Syrian political system.

Finally, there is a negative relationship with Egypt since the revolution of June 30, 2013, which it considers a coup, while seeking to re-improve relations with the Egyptian political system.

\section{References}

Abdel-Meguid, S. (2012, December 20). Turkey and the Arab Spring. Al Ahram Weekly, 1127. Retrieved from http://weekly.ahram.org.eg/News/600/-/-.aspx

Ardito, A. M. (2015). Machiavelli and modern state. Publisher: Cambridge University Press, UK.

Arslantas, D. (2013). The political analysis of the Muslim Brotherhood and the AKP tradition: Why did Turkish model fail in Egypt (Master thesis, Middle East Technical University, 2013).

Barkey, H. J. (2011). Turkish foreign policy and the Middle East. CERI Strategy papers.

Cagaptay, S., \& Sievers, M. J. (2015), Turkey and Egypt's great game in the Middle East. The Washington Institute. Retrieved from http://www.washingtoninstitute.org/policy-analysis/view/turkey-and-egypts-great-game-in-the-middle-east 
Cengiz, S. (2015). How to read Turkey's stance in Yemeni crisis. Retrieved from http://english.alarabiya.net/en/views/news/middle-east/2015/03/29/How-to-read-Turkey-s-stance-on-the-Yemen-crisis.html CIDOB. (2011). CIDOB international year book 2011. Country profile: Turkey. Spain: Barcelona Centre for International Affairs. Craeyvelt, N. V. (2013). A discourse on (the absence of) military intervention: A comparative analysis of Libya and Syria (Master thesis, Antwerpen University, 2013).

Doha Institute. (2011). Turkey's position on the Libyan Revolution Report. Arab Center for Research and Policy Studies (ACRPS), Doha, March 2011. Retrieved from http://english.dohainstitute.org/file/get/d8319566-dac2-456c-b118-abe691fec24c.pdf

Habibi, N., \& Walker, J. W. (2011). What is driving Turkey's reengagement with the Arab World. Crown Center for Middle East Studies, 49, 1-10.

Hürriyet Daily News. (2011, January 2). Turkish PM Erdoğan urges Mubarak to heed Egyptian outcry. Retrieved from http://www.hurriyetdailynews.com/default.aspx?pageid=438\&n=turkey-calls-on-mubarak-to-heed-calls-for-change-2011-0201

Kibaroglu, M. (2012). What went wrong with "zero problem with neighbors" doctrine? Turkish Policy Quarterly, 11(3), 85-93.

Kirkpatrick, D. D. (2011, September 13). Premier of Turkey takes role in region. New York Times. Retrieved from http://www.nytimes.com/2011/09/13/world/middleeast/13egypt.html?

Laciner, S. (2009). Turgut Ozal period in Turkish Foreign Policy: Ozalism. USAK Yearbook of Politics and International Relations, 2, 153-205.

Lindenstrauss, G. (2012). Turkey and Arab Spring: Embracing "people power". Publisher: European Institute of the Mediterranean.

Murinson, A. (2012). Turkish foreign policy in the twenty first century. Mideast Security and Policy Studies, 97, 1-31.

Ozkan, M., \& Korkut, H. (2013). Turkish foreign policy towards the Arab revolutions. Epiphany: Journal of Transdisciplinary Studies, 6(1), 33-47.

Patrick, T. (2004). Turkey's Justice and Development Party: A model for democratic Islam? Middle East Intelligence Bulletin, 6(6). Retrieved from https://www.meforum.org/meib/articles/0407_t1.htm

Reuters. (2011). Tunisia revolt could be a model for others-Turkey. Retrieved February 21, 2011, from http://af.reuters.com/article/libyaNews/idAFLDE71K0PC20110221

Saadan, A. (2012). The attitudes of Turkish foreign policy towards Yemen during the Yemeni uprising of 2011; attitudes and perceptions. Retrieved from https://www.academia.edu/

Salem, P. (2012). Turkey's image in the Arab world. Turkish Economic and Social Studies Foundation (TESEV). Retrieved from http://tesev.org.tr/wp-content/uploads/2015/11/Turkeys_Image_In_The_Arab_World.pdf

Sumer, F. (2013). Turkey's changing foreign policy and Arab Spring. The public Sector Innovation Journal, 18(1), 1-28.

Takim, A., \& Yilmaz, E. (2010). Economic policy during Ataturk's era in Turkey (1923-1938). African Journal of Business Management, 4, 549-554.

The Tripoli Post. (2012, May 10). Turkish exports to Libya on increase. Retrieved from http://www.tripolipost.com/articledetail.asp?c=2\&i=8333

Tremblay, P. (2013). Diplomacy faces challenge in Yemen. Retrieved from http://www.al-monitor.com/pulse/originals/2013/03/turkey-yemen-public-diplomacy-aid-gun-shipments.html

Walker, J. W. (2007). Learning strategic depth: Implications of Turkey’s new foreign policy doctrine. Insight Turkey, 9(3), 33-47. 